\title{
Trend of studies on carbon sequestration dynamics in the Himalaya hotspot region: A review
}

\author{
Darshana Tolangay \\ Department of Botany, University of Calcutta, 35, B.C. Road, Kolkata-700019 (West Bengal), \\ India \\ Saurav Moktan* \\ Department of Botany, University of Calcutta, 35, B.C. Road, Kolkata-700019 (West Bengal), \\ India \\ *Corresponding author. Email: smbot@caluniv.ac.in
}

\author{
Article Info \\ https://doi.org/10.31018/ \\ jans.v12i4.2426 \\ Received: November 1, 2020 \\ Revised: December 8, 2020 \\ Accepted: December 12, 2020
}

\section{How to Cite}

Tolangay D. and Moktan S. (2020). Trend of studies on carbon sequestration dynamics in the Himalaya hotspot region: A review. Journal of Applied and Natural Science, 12(4):647 - 660. https://doi.org/10.31018/jans.v12i4.2426

\begin{abstract}
The present communication deals with the carbon dynamics in the Himalaya hotspot region. The Himalaya, a mountain range shared by Pakistan, India, Nepal, Bhutan and Myanmar, is one of the biologically richest regions in the world that play an important role as source and sink in global carbon cycle. The purpose of this paper was to review and provide available studies related to carbon sequestration in the Himalayas. The carbon in forest is stored in five different pools viz. above-ground biomass, below-ground biomass, litter, deadwood and soil organic carbon. Estimates of biomass, carbon stock and soil organic carbon contents by almost all forest types including agroforestry systems and plantations in the Himalaya hotspot have been documented in this communication. The net rate of carbon sequestrated by forest was reported to be $2.4 \pm 0.4 \mathrm{Pg} \mathrm{C}^{-1}$ on a global scale. The Indian Himalayan Region constitutes about 5.4 billion tonnes of $C$ and sequesters about 65 million tonnes of $C$ $\mathrm{yr}^{-1}$. We analysed more than 135 peer-reviewed journal articles related to biomass and carbon sequestration. The review identifies that the studies estimated 3697.05, 3898.10 and 4235.05 tonnes carbon per hectare for Western, Central and Eastern Himalayan region respectively. The research on the biomass/carbon estimation received attention as early as 1980 s, but increased gradually after 2001. These findings would contribute to policy-makers with useful information for mitigation of $\mathrm{CO}_{2} \mathrm{emissions}$.
\end{abstract}

Keywords: Biomass, Carbon dioxide, Carbon sequestration, Forests, Himalaya hotspot

\section{BACKGROUND}

The United Nations Framework Convention on Climate Change (UNFCCC) in 1992 aims to stabilize Green House Gases emissions in the atmosphere (Pires et al., 2011). The carbon dioxide $\left(\mathrm{CO}_{2}\right)$ is the most concerned greenhouse gas (GHG), which is the primary cause for the increasing concentration of atmospheric GHGs, influencing the global environment (Brown, 1993). In recent millennia, global warming has become a very problematic issue (Mishra et al., 2014). The warming of Earth is strongly associated with the sequestration of $\mathrm{CO}_{2}$ degassed from the inside of Earth (Gaillardet and Galy, 2008). The increase in $\mathrm{CO}_{2}$ emission since the onset of industrial revolution from 280 parts per million (ppm) is projected to lead to $540 \mathrm{ppm}$ by the year 2100 (Alamgir and Al-Amin, 2007). The main source behind the rising atmospheric $\mathrm{CO}_{2}$ level is due to fossil fuels combustion and human induced activities (Bolin, 1977; Joshi and Dhyani, 2019). Reduction of $\mathrm{CO}_{2}$ emission and storage of carbon are the faithful options to mitigate climate change and global warming (Kusmana et al., 2018). During the $20^{\text {th }}$ century, there has been a distinct rise in the sea-level along with the change in ecosystems and the rate of occurrence of forest fire either by human actions or natural events (Lal, 2008).

Carbon $(C)$ is a primary component of all known life on Earth, representing approximately $50 \%$ of dry forest biomass (Kebede and Soromessa, 2018). It is the fourth most abundant element in the universe by mass after hydrogen, helium, and oxygen. The exchange of $\mathrm{C}$ among three reservoirs viz. the atmosphere, terrestrial biosphere and ocean, is known as the carbon cycle (Post et al., 1990). Forests are significant component of the global carbon cycle because they acts as carbon source or as carbon sink (Masera et al., 2003). About $30 \%$ of global land area is under permanent forest cover (Whitehead, 2011).

Forest represents a major carbon pool, comprising approximately $60 \%$ of terrestrial carbon storage (Sandeep et al., 2014). Tropical, boreal and temperate 
forests are estimated to store roughly between 378 to 564, 249 to 295 , and 113 to $125 \mathrm{Pg} \mathrm{C}$, respectively, of the existing carbon (Pan et al., 2011). The Kyoto Protocol, recognizes forestry as a sink measure under the Clean Development Mechanism (CDM) but only in form of afforestation and reforestation (Arora and Chaudhry, 2014). India, being a signatory member to the Kyoto Protocol, carried out numerous studies in the country (Salunkhe et al., 2018).

The Intergovernmental Panel on Climate Change (IPCC) and Reducing Emission from Deforestation and Forest Degradation (REDD) mechanisms provides guidelines for enhancing carbon sequestration and reducing deforestation (Vieilledent et al., 2012). The process of removal or capture of the atmospheric carbon dioxide into other long-lived $\mathrm{C}$ pools is called 'Carbon Sequestration' (Dhanwantri et al., 2014). Carbon sequestration is defined by the UNFCCC as "the process of removing carbon from the atmosphere and depositing it in a reservoir" (Nair, 2012). Carbon Dioxide Removal (CDR) is referred as "a set of techniques that aim to remove $\mathrm{CO}_{2}$ directly from the atmosphere by either (1) increasing natural sinks for carbon or (2) using chemical engineering to remove the $\mathrm{CO}_{2}$, with the intent of reducing the atmospheric $\mathrm{CO}_{2}$ concentration" (IPCC, 2012b). Through sequestration activities, global climate change could be prevented by enhancing carbon stock in trees and soils, by reducing $\mathrm{CO}_{2}$ and other GHGs emissions, and by preserving existing carbon of trees and soils. Carbon is therefore sequestered biologically in the forest ecosystem (Khurana, 2012).

Globally from 1990 to 2007 , the net rate of $C$ sequestrated by forest was $2.4 \pm 0.4 \mathrm{Pg} \mathrm{C} \mathrm{yr}^{-1}$ (Zhang et al., 2019). Carbon sequestration by forests has attracted much interest world-wide as a mitigation approach. The emissions of $\mathrm{CO}_{2}$ have increased continuously during the recent decades. In 2018, the $\mathrm{CO}_{2}$ emissions from fossil fuels raised to $10.0 \pm 0.5 \mathrm{Gt} \mathrm{C} \mathrm{yr}^{-1}$, those from land use change was assessed as $1.5 \pm 0.7 \mathrm{Gt} \mathrm{C}$ $\mathrm{yr}^{-1}$ and the global average annual concentration of atmospheric $\quad \mathrm{CO}_{2}$ resulted $407.38 \quad \pm 0.1 \mathrm{ppm}$ (Friedlingstein et al., 2019). Carbon emissions from India report an estimation of 2,607.49 million tonnes $\mathrm{CO}_{2}$ equivalent (FSI, 2019). According to the Global Energy and $\mathrm{CO}_{2}$ Status Report (IEA, 2019). India emitted 2,299 million tonnes of $\mathrm{CO}_{2}$ equivalent in 2018 . India's emissions rose by $4.8 \%$ from last year due to a rise in coal consumption. In the terrestrial ecosystem, the carbon is stored in five different pools viz. aboveground biomass (AGB), below-ground biomass (BGB), litter, deadwood and soil organic carbon (Yaklaşımlar, 2012). The AGB includes all living biomass above the soil (stem, stump, branches, bark, seeds and foliage) and the BGB includes all live roots (Penman et al., 2003). Estimation of $A G B$ is very important to access carbon stocks changes (Manickam et al., 2014).

\section{BIODIVERSITY HOTSPOTS}

The concept of biodiversity hotspots was first introduced by Norman Myers, a biologist, in the year 1988 and identified 10 hotspot areas in tropical forests (Myers, 1988). Two years later, 8 other hotspot areas were recognized, four in tropical forests and four in Mediterranean-type ecosystems (Myers, 1990). Conservation International and MacArthur Foundation adopted Myers concept of hotspots in 1989 (Mittermeier et al., 1998). The number of hotspots increased to 25 , covering $1.4 \%$ of Earth's land area, containing $44 \%$ of world's plant species and $35 \%$ of vertebrate species. Presently, there are 36 recognized biodiversity hotspots that covers $2.4 \%$ of Earth's land with Forests of East Australia and North American Coastal Plain being identified in 2011 and 2016, respectively (CEPF, 2019). India being one of the Megadiverse country with diverse biogeographical and climatic conditions, ranging from the cold and high Himalayas in the north to the hot and humid peninsula in the south, and from the wet, green, north-eastern forest to the dry north-western desert harbours four biodiversity hotspots: the Himalaya, the Indo-Burma region, the Western Ghats-Sri Lanka and the Sundaland (Venkataraman and Sivaperuman, 2018).

\section{THE HIMALAYA HOTSPOT}

The word "Himalaya" is derived from Sanskrit, meaning the "abode of snow" (Hima-snow and alaya-abode) (Negi, 2009). The magnificent Himalaya, a geologically young mountains (Singh and Rawat, 1999) is well notable to the South Asia and in addition to the Earth for its diversity of ecosystems (Sharma et al., 2008). The Himalaya biodiversity hotspot extends in a curve 3,000 $\mathrm{km}$ of northern Pakistan, Nepal, Bhutan and the northwestern and north-eastern parts of India (Fig. 1). With an area approximately $750,000 \mathrm{sq}$. $\mathrm{km}$, the mountain range of Himalaya has been broadly classified into three provinces: the Western Himalaya (the north-west Kashmir, Himachal Pradesh, Uttarakhand and northern Pakistan); the Central Himalaya (the Garhwal and Kumaun) and the Eastern Himalaya (the parts of $\mathrm{Ne}$ pal, Bhutan, the north-east Indian states of West Bengal, Sikkim, Assam, Arunachal Pradesh, south-east Tibet and northern Myanmar) (Sharma, 1999). The population of the Himalaya belongs to four distinct ethnic groups i.e., Indie, Tibetan, Afghan-Iranian and Burman or Southeast Asian people (Karan, 1987). In 2011, the Himalaya's population has reached $52,776,118$ people. Out of the total population, the Western Himalaya is inhabited by $25,592,222$ people, the Central Himalaya by $19,220,834$ and the Eastern Himalaya by $7,963,062$ people (Apollo, 2017). The protected area network in the Himalaya hotspot comprises of 55 National Parks, 146 Wildlife Sanctuaries, 6 Biosphere Reserves and 7 World Heritage sites (Seeland, 2000; Shrestha et al., 2010; Beffasti and 
Galanti, 2011; ENVIS, 2019).

The Himalayas and connected moist regions in the South Asia harbour extra-tropical broadleaved evergreen forest, a type generally ignored in analyses of forest responses to global change (Zobel and Singh, 1997).

The Indian Himalayan Region (27 $50^{\circ}$ to $37^{\circ} 06^{\prime} \mathrm{N}$ and $72^{\circ} 30^{\prime}$ to $97^{\circ} 25^{\prime} \mathrm{E}$ ) forms the largest part of the Himalaya and stretches over 5.37 lakh sq. km from Jammu \& Kashmir in the northwest to Arunachal Pradesh in the northeast, and fully covering ten states viz. Jammu \& Kashmir, Himachal Pradesh, Uttarakhand, Sikkim, Arunachal Pradesh, Meghalaya, Mizoram, Nagaland, Tripura and Manipur while partially covers only the hill districts of Assam and West Bengal. It contributes about $16.2 \%$ of India's total geographical area and more than $41.5 \%$ is accounted by a rich forest cover (Kumar et al., 2018). Of the estimated 18,440 species of plants in the Indian Himalayan Region (IHR), about $25.3 \%$ are endemic to the Himalaya that include 1748 medicinal plants, 675 wild edibles, 279 fodder species, 155 sacred plants, 118 essential oil plants with medicinal values (Stephen et al., 2015).

\section{CARBON DYNAMICS IN THE HIMALAYAS}

The Himalayas have several influences on the global carbon cycle. To determine whether they are net sources or sinks of atmospheric $\mathrm{CO}_{2}$ can only be determined by considering the significance of biomass, net primary production and exploitation rates (Singh et al., 1985). The Himalayan forests have become a net source of $\mathrm{CO}_{2}$ to the atmosphere due to overexploita- tion. On the basis of forest management activities done in community forests, the Indian Himalayan Region (IHR) constitute about 5.4 billion tonnes of $\mathrm{C}$ and

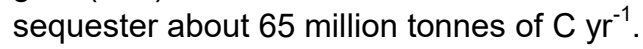

In India, the sum of annual $\mathrm{C}$ sequestered is approximately equal to $15 \%$ of the $\mathrm{CO}_{2}$ emissions from fossil fuels (Singh et al., 2010). Therefore, the Himalayan forests can be considered as a carbon sink. In the forest ecosystems, accumulated biomass is an important feature for assessing sustainable utilization, productivity and the amount of $\mathrm{CO}_{2}$ sequestered from the atmosphere. The accuracy of biomass estimation is therefore, very important for numerous applications like global carbon cycle, timber extraction and to track carbon stock changes (Vashum and Jayakumar, 2012; Kaushal et al., 2016). The aboveground forest biomass have been estimated by various methods through field measurement, tree inventories data, species-specific biomass estimation, remote sensing and geographical information systems (GIS) methods (Brown et al., 1989, 1999; Lu, 2006; Murali et al., 2005).

Field measurement method is classified into two types, viz., destructive and non-destructive biomass estimation methods. The destructive method also known as harvest method, is the direct method for estimation of aboveground forest biomass and carbon stock (Gibbs et al., 2007) and consists of cutting or harvesting of trees of the given area followed by weighing the different components of the harvested tree like trunk, leaves and branches (Lodhiyal and Lodhiyal, 2003; Xiao and Ceulemans, 2004; Ravindranath and Ost-

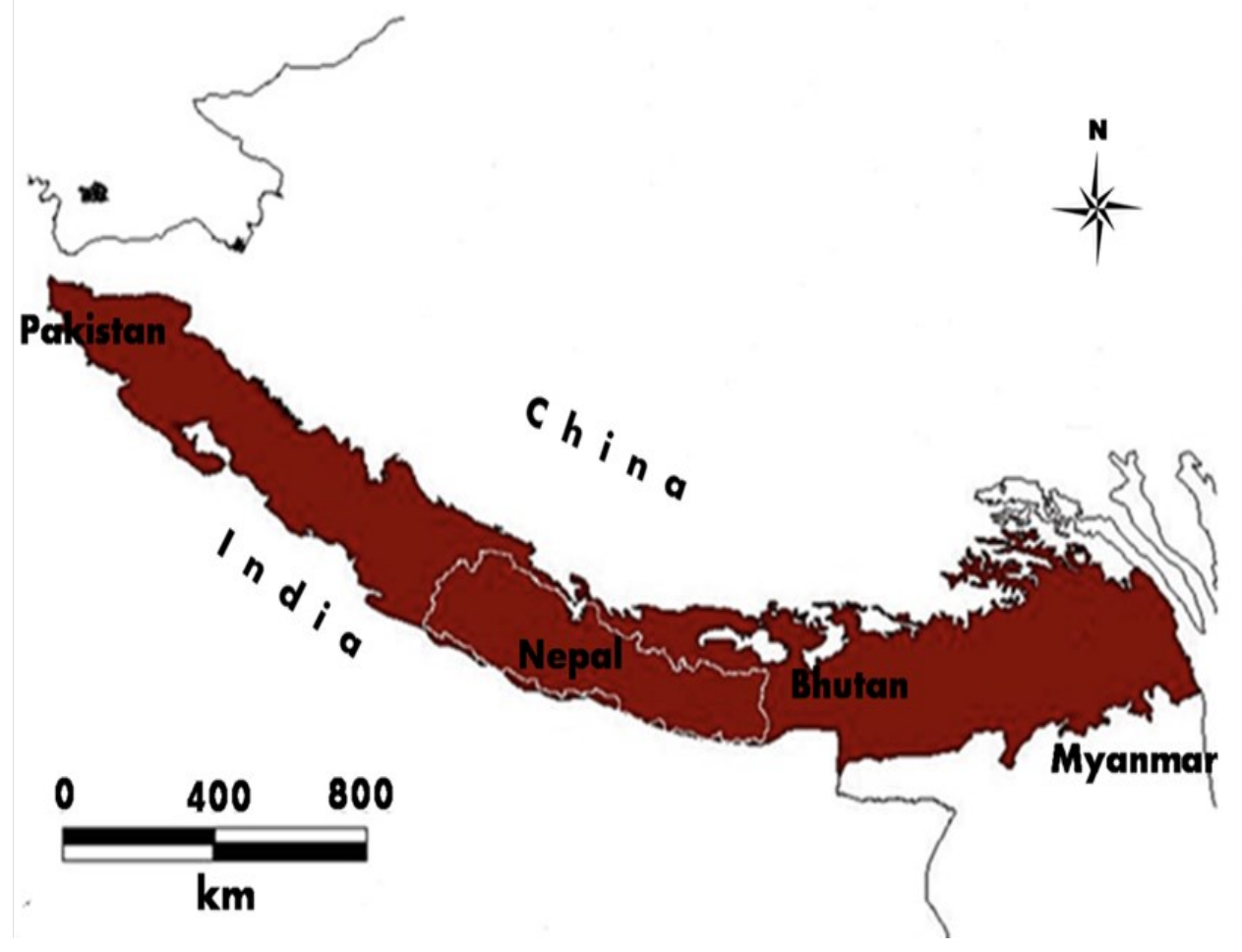

Fig.1. Map of Himalaya Hotspot region. 
wald, 2008; Devi and Yadava, 2009). This method is expensive, destructive and time-consuming and could be applied to small tree sample sizes and small plots (Ketterings et al., 2001) and also not applicable in degraded forests containing threatened species (Montes et al., 2000). The non-destructive method of biomass estimation is assessed by two-dimensional analytical techniques, on the basis of relationships between biomass and measurable parameters, like girth at breast height (GBH) (Aboal et al., 2005). This method is used to get an estimate of biomass and allometric equation preparation on larger-scale forest (Bhandari and Neupane, 2014). Another method for estimation of biomass is remote sensing and GIS. It is an alternative to traditional methods for biomass estimation and forest's carbon stocks (Ravindranath and Ostwald, 2008). Several studies have been conducted applying remote sensing techniques to estimate the biomass of forest (Nelson et al., 1988; Hame et al., 1997; Drake et al., 2003; Anaya et al., 2009; Hudak et al., 2012; Koppad et al., 2020). However, the data from field is usually essential for authentication.

\section{WESTERN HIMALAYA}

The Western Himalaya (Latitude $28^{\circ} 43^{\prime} \mathrm{N}$ to $37^{\circ} 05^{\prime} \mathrm{N}$ and Longitude $72^{\circ} 31^{\prime} \mathrm{E}$ to $81^{\circ} 01^{\prime} \mathrm{E}$ ) extends from Badshahkahan in North Eastern Afghanistan upto Central Nepal. In India, states of Jammu and Kashmir, Himachal Pradesh and Uttarakhand fall in this region (Bhatt et al., 2016). Chisanga et al. (2018) studied the carbon stock in Kinnaur district of Himachal Pradesh based on land use and altitudinal ranges. The biomass estimation was species and region specific including form factor for tree volume. The maximum estimation was AGB (84.65 ton ha $\left.{ }^{-1}\right)$, BGB (19.50 ton ha $\left.{ }^{-1}\right)$, and total biomass $\left(104.10\right.$ ton $\left.\mathrm{ha}^{-1}\right)$. The total ecosystem carbon density of 166.36 ton ha ${ }^{-1}$ and soil carbon density of 155.77 ton $^{-1}{ }^{-1}$ were recorded.

Goswami et al. (2014) evaluated biomass and carbon sequestration based on non-destructive method in the different agroforestry land use systems of the Kwalkhad watershed of middle Himalayan region and recorded C stocks as $14.78 \mathrm{Mg} \mathrm{C}^{-1}$ for agrisilvihorticulture and $14.45 \mathrm{Mg} \mathrm{C} \mathrm{ha}^{-1}$ for agrihortisilviculture. The greatest number of $C$ credits $(1 \mathrm{C}$ credit $=1$ ton $\mathrm{CO}_{2}$ ) was produced by agrisilvihortivulture $\left(21.49 \mathrm{ha}^{-1}\right)$, while the lowest by silvipasture $\left(5.46 \mathrm{ha}^{-1}\right)$. Palchowdhuri et al. (2016) estimated the change in the AGB and carbon stock for three major forest types in Shimla as a consequence to landuse dynamics using NDVIbased approach. It was found that the correlation between carbon stock and NDVI values was significant $(r$ $=84 \%$ for 2003 and $80 \%$ for 2013). In the sub-tropical forests of Himachal Pradesh, comparable study was carried out by (Bhardwaj et al., 2016).

Aziz et al. (2019) assessed the biomass and soil carbon stocks in the alpine and subalpine regions of Kashmir where the average carbon stocks of 372.5 ton $\mathrm{ha}^{-1}$, biomass carbon of 2.27 ton ha ${ }^{-1}$ and the soil organic carbon stocks of 370.6 ton ha $^{-1}$ were recorded. Dad (2019) conducted a study to estimate soil organic carbon (SOC) stocks in 20 grasslands of Kashmir Himalaya and showed high variable results in SOC stocks ranging between 28.85 and $94.76 \mathrm{Mg} \mathrm{C} \mathrm{ha}^{-1}$, with mean value of $54.52 \mathrm{Mg} \mathrm{C}^{-1}$.

As per Shaheen et al. (2016), carbon stocks in living trees of different subtropical forest types in Kashmir ranged from 326 ton ha ${ }^{-1}$ on Pinus roxburghii to 75.86 ton $\mathrm{ha}^{-1}$ on mixed forest, with total carbon stock of 186.27 ton ha $^{-1}$. The estimated average biomass carbon was 151.38 ton ha ${ }^{-1}$ with calculated soil carbon stocks as 34.89 ton ha ${ }^{-1}$ and agricultural soil carbon of 27.18 ton ha ${ }^{-1}$. Dar et al. (2017) studied the temperate forests of Kashmir Himalaya and estimated an average dry biomass of 234.2 ton $^{-1}{ }^{-1}, A G B$ and BGB of 223 ton ha ${ }^{-1}$, understorey vegetation of 1.3 ton ha ${ }^{-1}$ and detritus of 9.9 ton ha ${ }^{-1}$. Similar type of study was conducted by (Dar and Sahu, 2018) in temperate forests of northern Kashmir Himalaya. Rashid et al. (2017) assessed the changes in the AGB and carbon stocks of Lidder valley, Kashmir Himalaya, using satellite data, phytosociological data and allometric equation for 33 years and found a strong correlation between land use land cover (LULC) and C dynamics of forest with NDVI and biomass. Also about $1.018 \mathrm{Mg}$ of aboveground biomass and $0.5 \mathrm{Mg}$ of aboveground carbon was lost from the area. For estimation of biomass across a chronosequence of Chir Pine forest in Murree Hill of Pakistan, Amir et al. (2018) used field inventory data based on basal area, height and form factor and reported overall mean carbon values from 90.3 ton ha ${ }^{-1}$ to 309.5 ton ha ${ }^{-1}$.

Uddin et al. (2019) analysed the soil, species composition and carbon stock in the Abies pindrow dominant community in Dir Kohistan, Pakistan and found that the stem density ranged between $3 \mathrm{ha}^{-1}$ in Acer caesium to 273 ha $^{-1}$ in Abies pindrow, with 350 trees ha $^{-1}$ as a total stand density. The total biomass carbon and the total average carbon stock were 967 ton ha ${ }^{-1}$ and 568.63 ton ha ${ }^{-1}$, respectively.

Rajput et al. (2015) conducted a study to estimate the biomass, carbon density and $\mathrm{CO}_{2}$ mitigation potential of 7 different land use systems along an altitudinal gradient in north-western Himalayas with results showing highest AGB and BGB estimates at orchard + cerealcereal system as $75.64 \mathrm{Mg} \mathrm{ha}^{-1}$ and $23.60 \mathrm{Mg} \mathrm{ha}^{-1}$, respectively; highest $\mathrm{CO}_{2}$ mitigation potential at altitudinal range of $1,900-2,200 \mathrm{~m}$ as $7.81 \mathrm{Mg} \mathrm{ha}^{-1} \mathrm{yr}^{-1}$ and highest carbon density of both soil + plant at altitudinal range of $1,300-1,600 \mathrm{~m}$ as $90.88 \mathrm{Mg} \mathrm{ha}^{-1}$. Rai et al. (2020) assessed the dry matter dynamics of forests along treeline ecotone in Kedarnath Wildlife Sanctuary, Western Himalaya by adopting regional specific allometric equations for the biomass and net primary productivity (NPP). The average forest biomass of $33.27 \pm 16.97 \mathrm{Mg} / 0.1 \mathrm{ha}$, ranging from $8.87 \mathrm{Mg} / 0.1 \mathrm{ha}$ 
to $44.98 \mathrm{Mg} / 0.1$ ha and NPP range from 1.49 to 2.11 $\mathrm{Mg} / 0.1$ ha year ${ }^{-1}$ was estimated.

For the estimation of aboveground and belowground biomass, Toky and Bisht (1993) used harvest method and reported AGB (kg/tree) from 11.6 to 37.5 , BGB (kg/tree) from 2.2 to 8.7 and NPP ranging from 0.98 to $9.33 \mathrm{~kg} /$ tree/year in important fuel wood trees from arid north-western India. Mandal and Joshi (2015) calculated aboveground biomass and carbon stocks of an invasive woody shrubs applying allometric equation in the subtropical deciduous forests of Doon Valley, western Himalaya, India. Results indicated the maximum coverage $\left(58.57 \% \mathrm{ha}^{-1}\right)$, highest biomass $\left(13,559.60 \mathrm{~kg} \mathrm{ha}^{-1}\right)$ and carbon density (6373.01 kg $\mathrm{ha}^{-1}$ ) of Lantana camara. Vaidya et al. (2017) developed allometric equations to estimate biomass and soil carbon stock in subtropical-subtemperate regions of Western Himalaya. The mean biomass and soil carbon stock ranged from 150.50 to 544.94 ton ha ${ }^{-1}$ for different farm plantations. In the plantation forests of north western Himalaya, Devi et al. (2012) estimated biomass and carbon sequestration of $185.57 \pm 48.99$ and $42.47 \pm 10.38$ ton $\mathrm{ha}^{-1}$ in Ulmus villosa with highest vegetation carbon density of $118.37 \pm 1.49$ ton $^{-1}$ in $^{-1}$ Albizia procera and lowest in Acacia catechu (36.50 \pm 9.87 ton $\left.\mathrm{ha}^{-1}\right)$. The highest soil carbon density was $219.86 \pm 10.34$ ton ha $^{-1}$ in Alnus nitida, and lowest in Pinus roxburghii $\left(170.83 \pm 20.60\right.$ ton $\left.\mathrm{ha}^{-1}\right)$. The highest $\mathrm{CO}_{2}$ mitigation potential (29.09 \pm 12.78 ton $\left.\mathrm{ha}^{-1}\right)$ and carbon sequestration $\left(7.91 \pm 3.4\right.$ ton $\left.\mathrm{ha}^{-1}\right)$ was in Ulmus villosa. Shahid and Joshi (2015) conducted a study to estimate biomass and carbon stock in the three forest ranges of Doon valley, Western Himalaya using volumetric equations where biomass varied from 338.40 to $438.17 \mathrm{Mg} \mathrm{ha}^{-1}$ and carbon stocks from 169.20 to $219.08 \mathrm{Mg} \mathrm{C}^{-1}$ (Table 1). Giri et al. (2014), developed Biomass Expansion Factor (BEF) and estimated carbon pool in Ailanthus excela with total biomass of 126.07 ton ha ${ }^{-1}$, AGB of 102.96 ton ha $^{-1}$, BGB of 23.11 ton ha ${ }^{-1}$ and BEF value of 1.23 .

\section{CENTRAL HIMALAYA}

The Indian Central Himalaya is located in the centre of the Himalayan Mountain Range. Out of total geo- graphic area of 51,125 sq. $\mathrm{km}$ (Latitude $28^{\circ} 44^{\prime} \mathrm{N}$ to $31^{\circ}$ $25^{\prime} \mathrm{N}$ and Longitude $77^{\circ} 45^{\prime} \mathrm{E}$ to $\left.81^{\circ} 01^{\prime} \mathrm{E}\right), 92.6 \%$ is mountainous, which is called mainland. It comprises of two distinct divisions- Garhwal and Kumaun Himalayas, and is demarcated by Himachal Pradesh in the northwest, Haryana in the west, Uttar Pradesh in the south, Nepal in the east, and Tibet in the north (Sharma, 1999).

Sharma et al. (2011) assessed carbon stock on different slope aspects in seven major forest types of temperate region of Garhwal Himalaya, India. Results showed that minimum value of total tree $C$ density of $77.3 \mathrm{Mg} \mathrm{Cha}^{-1}$ on South-East (SE) aspect and maximum value of $291.6 \mathrm{Mg} \mathrm{C} \mathrm{ha}^{-1}$ on North-East (NE) aspect and soil organic carbon ranged from 40.3 Mg C ha ${ }^{-1}$ on SW aspect and $177.5 \mathrm{Mg} \mathrm{C} \mathrm{ha}^{-1}$ on NE aspect. In moist temperate forest of Garhwal Himalaya, the total live tree biomass density (TBD) ranged from 215.5 to $486.2 \mathrm{Mg} \mathrm{ha}^{-1}$ and total live carbon density (TCD) ranged from 107.8 to $234.1 \mathrm{Mg} \mathrm{C} \mathrm{ha}^{-1}$. For the study area, the average values of TBD and TCD were $356.8 \pm 83.0 \mathrm{Mg} \mathrm{ha}^{-1}$ and $178.4 \pm 41.5 \mathrm{Mg} \mathrm{C} \mathrm{ha}^{-1}$, respectively (Gairola et al., 2011). In Balganga Reserved Forest (BRF) in Garhwal, Uttarakhand, estimation of forest carbon (C) stock was carried out by (Kumar and Sharma, 2015), where results showed the maximum total biomass density (TBD) and total carbon density (TCD) estimates at site III in the altitudinal range (1800 $-2600 \mathrm{~m}$ ) as 108.26 and $53.45 \mathrm{Mg} \mathrm{ha}^{-1}$ followed by site II in the range (1600-1800 $\mathrm{m}$ ) as 83.92 and 41.96 $\mathrm{Mg} \mathrm{ha}^{-1}$, and minimum at site $\mathrm{I}$ in the altitudinal range $(1000-1400 \mathrm{~m})$ as 57.22 and $28.61 \mathrm{Mg} \mathrm{ha}^{-1}$ with an average of 83.13 and $41.56 \mathrm{Mg} \mathrm{ha}^{-1}$, respectively.

Pala et al. (2016) conducted a study in four community based religious conserved forests areas of Garhwal Himalaya and estimated total carbon density of 782 trees ha $^{-1}$ to 1352 trees $\mathrm{ha}^{-1}$ and total basal cover (TBC) from $31.67 \mathrm{~m}^{2} \mathrm{ha}^{-1}$ to $84.34 \mathrm{~m}^{2} \mathrm{ha}^{-1}$. As per Mahato et al. (2016), total biomass density and total carbon density were $132.74 \mathrm{Mg} \mathrm{ha}^{-1}$ and $66.36 \mathrm{Mg} \mathrm{ha}^{-1}$ in community-managed forests of Garhwal Himalaya. Studies from various pure Conifer forest types of Garhwal Himalaya, showed maximum growing stock of $988.3 \mathrm{~m}^{3} \mathrm{ha}^{-1}$ in Abies pindrow forest, followed by $922.3 \mathrm{~m}^{3} \mathrm{ha}^{-1}$ for Cupressus torulosa (Dimri et al.,

Table 1. Carbon estimation in extensions of Western Himalaya.

\begin{tabular}{|c|c|c|c|c|c|c|c|}
\hline Region & $\begin{array}{l}\text { AGB } \\
\left(\text { tha }^{-1}\right)\end{array}$ & $\begin{array}{l}\text { BGB } \\
\left(\text { tha }^{-1}\right)\end{array}$ & $\begin{array}{l}\text { Deadwood } \\
\left(\text { tha }^{-1}\right)\end{array}$ & $\begin{array}{l}\text { Litter } \\
\left(\text { tha }^{-1}\right)\end{array}$ & $\begin{array}{l}\text { SOC } \\
\left(\text { tha }^{-1}\right)\end{array}$ & $\begin{array}{l}\text { Total } \\
\left(\text { tha }^{-1}\right)\end{array}$ & Source \\
\hline Doon Valley & 951.59 & 247.42 & - & - & - & 1199.01 & Shahid and Joshi (2015) \\
\hline Himachal Pradesh & 71.3 & 19.92 & 1.66 & 1.76 & 68.87 & 163.51 & FSI (2019) \\
\hline Uttarakhand & 62.77 & 16.86 & 1.21 & 2 & 69.76 & 152.62 & FSI (2019) \\
\hline Punjab & 19.09 & 7.4 & 0.14 & 0.67 & 44.89 & 72.18 & FSI (2019) \\
\hline Kashmir Himalaya & 1261.4 & 252.3 & - & - & 174.47 & 1688.17 & Shaheen et al. (2016) \\
\hline Haryana & 15.32 & 5.8 & 0.11 & 0.86 & 43.23 & 65.31 & FSI (2019) \\
\hline Pakistan & 33.97 & 6.63 & - & - & 315.65 & 356.25 & Aziz et al.(2019) \\
\hline
\end{tabular}

Abbreviations: AGB-Above Ground Biomass; BGB-Below Ground Biomass; SOC-Soil Organic Carbon; tha ${ }^{-1}$ - Tonnes per hectare 
2014). Similarly, the total carbon density and $\mathrm{CO}_{2}$ mitigation potential in Oak and Pine forests of Garhwal, central Himalaya were $2420.54 \mathrm{Mg} \mathrm{C} \mathrm{ha}^{-1}$ and 8,713.94 $\mathrm{Mg} \mathrm{C} \mathrm{ha}^{-1}$ (Oak) and 986.93 $\mathrm{Mg} \mathrm{C} \mathrm{ha}^{-1}$ and $3552.95 \mathrm{Mg} \mathrm{C}^{-1}$ (Pine), respectively (Nautiyal and Singh, 2013).

Pant and Tiwari (2014), estimated tree biomass and carbon sequestration in Chir-Pine forests under various disturbance levels in Kumaun Central Himalaya where total biomass was 14.7 ton $\mathrm{ha}^{-1}$ at highly disturbed site, followed by 94.46 ton $\mathrm{ha}^{-1}$ in moderately disturbed forest, and 112.0 ton ha $^{-1}$ in protected forest. The carbon sequestration rate ranged from 0.60 (ton/ ha) per annum to 4.3 (ton/ha) per annum. Similarly, Jina et al. (2008) estimated rates of carbon sequestration and total carbon stock in degraded and nondegraded sites of Pine and Oak forests in Kumaun Central Himalaya and found variation in carbon stock from 242.56 to 290.62 ton $\mathrm{ha}^{-1}$ and 16.73 to 18.54 ton ha $^{-1}$, respectively, and in non-degraded and degraded Chir Pine sites it varied from 81.31 to 115.40 ton $^{-1}$ and 17.59 to 33.42 ton ha $^{-1}$, respectively. Similar studies on biomass and carbon sequestration in Oak and Pine forests of Kumaun Himalaya, were conducted by (Joshi et al., 2013; Gosain et al., 2015).

Kanime et al. (2013) carried out study for estimation of tree biomass and carbon sequestration in different tree -based systems of Central Himalayan Tarai region and found the highest total biomass of $94.8 \mathrm{Mg} \mathrm{ha}^{-1}$ and carbon stocks ranging from 4.51 $\mathrm{Mg} \mathrm{C} \mathrm{ha}^{-1}$ to 43.39 Mg C ha-1. Arora et al. (2014) assessed growth, biomass carbon storage and sequestration along an age series of Populus deltoides plantations at Tarai region of central Himalaya. Results showed that the total carbon stock increased from $64.4 \mathrm{Mg} \mathrm{C}^{-1}$ at 1 year to 173.9 Mg C ha ${ }^{-1}$ at 11 years. Sheikh et al. (2020) studied biomass and carbon stocks in temperate Cedrus deodara forests along the altitudinal gradients in the Central Himalaya and estimated carbon stock of 395.4 ton $\mathrm{ha}^{-1}$ for lower altitude, followed by 321.6 ton ha $\mathrm{ha}^{-1}$ and 282.5 ton $\mathrm{ha}^{-1}$ for middle and upper altitude respectively. At Banj Oak forests of Central Himalaya, total biomass stock ranged from $225.82 \pm 26.46$ ton ha $^{-1}$ to 595.50 \pm 5.64 ton $\mathrm{ha}^{-1}$ and total tree density showed a range from 920 ind ha ${ }^{-1}$ to 402.5 ind ha ${ }^{-1}$ (Pandey et al., 2020). Yadav et al. (2017), estimate biomass and carbon allocation in different production systems in the mid hills of
Indian Himalaya, and found the highest biomass of 56.5 ton $\mathrm{ha}^{-1}$ and carbon stocks of 25.3 ton $^{-1}$ in wheat + pecan nut system followed by 53.2 and 23.9 ton ha ${ }^{-1}$ in lentil + pecan nut system with the lowest of 2.75 and 1.17 ton $\mathrm{ha}^{-1}$ in pure lentil production system. The carbon stock and rate of carbon sequestration in pecan nut were 22.8 ton ha ${ }^{-1}$ and 1.67 ton ha ${ }^{-1}$ year $^{-1}$, respectively. Rana et al. (2015) made an assessment in the Cypress forest of Central Himalaya, and estimated the total biomass ranging between 178 and 431 ton ha $^{-1}$ while carbon stock varied between 89.07 and 206 ton ha ${ }^{-1}$. Similarly, Verma et al. (2012) studied the carbon storage capacity of Quercus semecarpifolia, forests of Central Himalayan region and observed the difference in the carbon biomass between 210.26 and 258.02 ton ha $^{-1}$ and mean carbon stock between 3.7 and 4.8 ton $\mathrm{ha}^{-1} \mathrm{yr}^{-1}$, respectively. Yadava (2011), carried out study under six different agroforestry systems, in Tarai region of Central, Himalaya. The biomass, carbon storage, $\mathrm{CO}_{2}$ mitigation potential and total carbon sequestration of trees were estimated. Adhikari et al. (2020) made an assessment of crop composition, yield, biomass, net primary productivity (NPP), carbon stock and carbon sequestration in agri-silviculture (AS) and agri-horticulture $(\mathrm{AH})$ agroforestry systems of Central Himalaya and showed the biomass and net primary productivity of trees as 128.3 ton $\mathrm{ha}^{-1}$ and 16.24 ton $\mathrm{ha}^{-1} \mathrm{yr}^{-1}$ in AS system while 171.95 ton ha ${ }^{-1}$ and 14.4 ton $\mathrm{ha}^{-1} \mathrm{yr}^{-1}$ in $\mathrm{AH}$ system (Table 2 ). The carbon sequestration of tree were 7.7 ton $\mathrm{ha}^{-1} \mathrm{yr}^{-1}$ for AS and 6.8 ton $\mathrm{ha}^{-1} \mathrm{yr}^{-1}$ for $\mathrm{AH}$ systems.

\section{EASTERN HIMALAYA}

The Eastern Himalaya,with total geographic coverage of $524,190 \mathrm{sq}$. $\mathrm{km}$ (Latitude $21^{\circ} 57^{\prime} \mathrm{N}$ to $29^{\circ} 27^{\prime} \mathrm{N}$ and Longitude $82^{\circ} 42^{\prime} \mathrm{E}$ to $100^{\circ} 18^{\prime} \mathrm{E}$ ) starts from the Kaligandaki Valley in central Nepal up to northwest Yunnan in China. The region includes Bhutan, parts of India (North East Indian states, and the Darjeeling hills of West Bengal), northern Myanmar, and southeast Tibet and parts of Yunnan in China (Tse-ring et al., 2010). Rai et al. (2018) estimated biomass and carbon stock across the timberline of Khangchendzonga National Park, eastern Himalaya and revealed that the total AGB ranged between $279.25 \pm 3.04$ and 15.35 $\pm 7.38 \mathrm{Mg} \mathrm{ha}^{-1}$ while the total $\mathrm{BGB}$ ranged between $144.76 \pm 8.10$ and $9.85 \pm 4.82 \mathrm{Mg} \mathrm{ha}^{-1}$, with the total

Table 2. Carbon estimation in extensions of Central Himalaya.

\begin{tabular}{|c|c|c|c|c|c|c|c|}
\hline Region & $\begin{array}{l}\text { AGB } \\
\left(\text { tha }^{-1}\right)\end{array}$ & $\begin{array}{l}\text { BGB } \\
\left(\text { tha }^{-1}\right)\end{array}$ & $\begin{array}{l}\text { Deadwood } \\
\left(\text { tha }^{-1}\right)\end{array}$ & $\begin{array}{l}\text { Litter } \\
\left(\text { tha }^{-1}\right)\end{array}$ & $\begin{array}{l}\text { SOC } \\
\left(\text { tha }^{-1}\right)\end{array}$ & $\begin{array}{l}\text { Total } \\
\left(\text { tha }^{-1}\right)\end{array}$ & Source \\
\hline Kumaun & 639.8 & 160.4 & - & - & - & 800.2 & Rana et al. (2015) \\
\hline Garhwal & 890.97 & 245.95 & - & 20.5 & 1646.2 & 2797.62 & Sheikh et al. (2020) \\
\hline Tarai & 239.36 & 60.92 & - & - & - & 300.28 & Adhikari et al. (2020) \\
\hline
\end{tabular}

Abbreviations: AGB-Above Ground Biomass; BGB-Below Ground Biomass; SOC-Soil Organic Carbon; tha ${ }^{-1}$ - Tonnes per hectare 
carbon content ranging between $195.03 \pm 2.32$ and $11.59 \pm 5.61 \mathrm{Mg} \mathrm{C}^{-1}$. Oo et al. (2006) assessed the biomass of the planted forests of 2 main species and biotic climax of shrub and grass communities in Myanmar. The biomass of the Eucalyptus camaldulensis forests ranged from 3.80 to $27.68 \mathrm{Mg} \mathrm{ha}^{-1}$ and that of the planted Acacia catechu forests was $10.62 \mathrm{Mg} \mathrm{ha}^{-1}$ whereas the biomass + litter weight of biotic climax of shrub and grass communities varied between 2.36 and $23.14 \mathrm{Mg} \mathrm{ha}^{-1}$.

For estimation of carbon sequestration, Thant et al. (2012) carried out study in mangrove plantations and a natural regeneration stand in the Ayeyarwady Delta, Myanmar and reported the total carbon stock of 73 $\mathrm{Mg}, 43 \mathrm{Mg}, 21 \mathrm{Mg}$ and $18 \mathrm{Mg} \mathrm{C}^{-1}$ in NR (Ceriops decandra, Bruguiera sexangula and Aegicerus corniculatum), Sonneratia apetala, Avicenia marina and Avicenia officinalis, respectively. Similarly, Aye et al. (2011) conducted a study in Myanmar and estimated the biomass and total carbon stock of Xylia xylocarpa (80.4 ton ha ${ }^{-1}$ and 120.5 ton ha ${ }^{-1}$ ) and of Pterocarpus macrocarpus (77.2 ton ha ${ }^{-1}$ and 130.8 ton ha ${ }^{-1}$ ). The total biomass carbon pool production in north-eastern India was $460.5 \mathrm{Mg} \mathrm{ha}^{-1}$, of which AGB and BGB contributed $91.20 \%$ and $8.8 \%$, respectively. Results indicate that, out of total biomass, $77 \%$ contribution was by Pinus kesiya, $13.5 \%$ broad-leaved tree species, $0.12 \%$ shrub, $0.03 \%$ herb and $0.5 \%$ litter. The annual NPP assessed was $17.5 \mathrm{Mg} \mathrm{ha}^{-1} \mathrm{yr}^{-1}$ (Baishya and Barik, 2011).

Baral et al. (2009) assessed the above-ground carbon stock in the five major forest types of Nepal using allometric equations and estimated the above-ground carbon stock per hectare and carbon sequestration rate ranging between $34.30-97.86$ dry wt. ton ha ${ }^{-1}$ and 1.30-3.21 ton $\mathrm{ha}^{-1} \mathrm{yr}^{-1}$, respectively. Similarly, Mandal et al. (2013) established allometric equations for Eucalyptus camaldulensis to estimate biomass of Sagarnath Forest, Nepal. Bhatta et al. (2018) studied carbon stock variation among trees of planted forest of Kathmandu, Central Nepal. The biomass of $418.2 \mathrm{Mg} \mathrm{ha}^{-1}$ and C-stock of 196.4 Mg C ha ${ }^{-1}$ were estimated. Using Sentinel 2 data, Pandit et al. (2018) made an assessment of AGB in sub-tropical buffer zone community forest in Parsa National Park, Nepal and estimated the average AGB of 153.04 ton ha ${ }^{-1}$. Poudel et al. (2011) estimated AGB of Cinnamomum tamala grown in the western hill regions of Nepal using destructive technique. The maximum AGB was in stem (47.24 \% tree${ }^{1}$ ) followed by leaves $\left(22.75 \%\right.$ tree $\left.^{-1}\right)$, branch $(19.69 \%$ tree $\left.^{-1}\right)$ and bark (10.31\% tree $\left.{ }^{-1}\right)$. Gurung et al. (2015) estimated carbon stock under different management regimes of tropical Sal forest in the Terai Nepal. The total $\mathrm{C}$ stock ranged from $291.55 \pm 42.51 \mathrm{Mg} \mathrm{C}^{-1}$ at protected areas, followed by $237.15 \pm 32.54 \mathrm{Mg} \mathrm{C}^{-1}$ for community forests, $189.16 \pm 26.46 \mathrm{Mg} \mathrm{C} \mathrm{ha}^{-1}$ for government-managed forests and $126.76 \pm 56.36 \mathrm{Mg}$ $\mathrm{C} \mathrm{ha}^{-1}$ in other forests. Similar study was assessed by
(Banik et al., 2018) in Sal forests under two management regimes in Tripura. Majumdar et al. (2016) estimated biomass of selected tropical forest patches of Tripura, with the help of allometric equations where biomass ranged between 37.85 to $85.58 \mathrm{Mg} \mathrm{ha}^{-1}$. Mishra and Sarkar (2019) studied the relationship between total organic carbon and soil carbon pools under different land management systems of Garo hills, Meghalaya, where maximum total organic carbon (TOC) were shown by tea gardens $\left(62.75 \pm 1.47\right.$ ton $\left.\mathrm{ha}^{-1}\right)$ and the minimum by jhum lands $\left(33.34 \pm 5.04\right.$ ton $\left.\mathrm{ha}^{-1}\right)$.

Rabha (2014), reported the average aboveground biomass of $239.45 \pm 12.8 \mathrm{Mg} \mathrm{ha}^{-1}$ and carbon stocks of $119.73 \pm 6.4 \mathrm{Mg} \mathrm{C} \mathrm{ha}^{-1}$ in an undisturbed regenerating Sal forest of Goalpara Assam. Kalita et al. (2017), estimated carbon stock applying species specific volume equations, wood-specific gravity, and biomass expansion factor at Tea agroforestry system of Barak valley, Assam. The carbon stock estimates in 6, 14, and 22 years old plantation were $44.8 \pm 1.3,50.2 \pm 4.6$, and 56.7 $\pm 4.9 \mathrm{Mg} \mathrm{C} \mathrm{ha}{ }^{-1}$, respectively. Similarly, towards the North-East India, Gogoi et al. (2017) estimated biomass and carbon stock of rain forest under the Dibrugarh Forest Division, using suitable regression equations.

Sharma et al. (2018) studied the diversity of trees and carbon stock of Hmuifang forest, Mizoram, using allometric equations. The results showed the total carbon stock and total $\mathrm{CO}_{2}$ sequestration of 468.26 ton $\mathrm{ha}^{-1}$ and 1718.5 ton ha ${ }^{-1}$, respectively. At Muli Bamboo forest of Mizoram, Devi and Singh (2019) estimated the rate of carbon stock as $50.25 \mathrm{Mg} \mathrm{C}^{-1}$ in Lengpui and $56.37 \mathrm{Mg} \mathrm{C} \mathrm{ha}^{-1}$ in Kelsih. Devi and Yavada (2015) carried out study for estimation of carbon stock and carbon sequestration rate in a tropical deciduous forest of Manipur, the AGB ranged between 18.2721.922 ton $\mathrm{ha}^{-1}$, the carbon stock from 9.13-10.96 ton $\mathrm{C} \mathrm{ha}^{-1}$ and the carbon sequestration rate differed from 1.4722 to 4.64136 ton ha $^{-1}$ year $^{-1}$. Thokchom and Yadava (2017) assessed biomass and carbon stock in ten forest stands along an altitudinal gradient in the forest of Manipur where AGB ranged between 124.56 and 254.99 ton ha $^{-1}$ and carbon stock ranged from 60.09 to 121.43 ton ha ${ }^{-1}$. Niirou and Gupta (2017) analysed carbon stocks in different form of land uses in Senapati district of Manipur. The results indicated the carbon stocks ranging from 25.51-164.81 ton ha ${ }^{-1}$.

Tshering (2019) made an assessment of $C$ stocks in Western Bhutan Himalaya and recorded highest biomass and carbon stock from Thimpu forest with $62.306 \mathrm{Mg} \mathrm{ha}^{-1}$ and $31.153 \mathrm{Mg} \mathrm{C} \mathrm{ha}^{-1}$, followed by $55.503 \mathrm{Mg} \mathrm{ha}^{-1}$ and $27.752 \mathrm{Mg} \mathrm{C}^{-1}$ har Khasadrapchu forest, $41.556 \mathrm{Mg} \mathrm{ha}^{-1}$ and $20.778 \mathrm{Mg} \mathrm{C}^{-1} \mathrm{har}^{-1}$ Chamgang forest and $32.133 \mathrm{Mg} \mathrm{ha}^{-1}$ and $16.066 \mathrm{Mg}$ $\mathrm{C}$ ha $^{-1}$ for Gidakom forest, respectively (Table 3 ). Tashi et al. (2017) based on harvest method estimated biomass and carbon stocks of forests along altitudinal gradient in the eastern Himalayas and found the aboveground $\mathrm{C}$ stocks increased with altitude from 57 
Table 3. Carbon estimation in extensions of Eastern Himalaya.

\begin{tabular}{llllllll}
\hline Region & $\begin{array}{l}\text { AGB } \\
\left(\text { tha }^{-1}\right)\end{array}$ & $\begin{array}{l}\text { BGB } \\
\left(\text { tha }^{-1}\right)\end{array}$ & $\begin{array}{l}\text { Deadwood } \\
\left(\text { tha }^{-1}\right)\end{array}$ & $\begin{array}{l}\text { Litter } \\
\left(\text { tha }^{-1}\right)\end{array}$ & $\begin{array}{l}\text { SOC } \\
\left.\text { (tha }^{-1}\right)\end{array}$ & $\begin{array}{l}\text { Total } \\
\left.\text { (tha }^{-1}\right)\end{array}$ & Source \\
\hline Myanmar & 66.14 & 12.75 & - & 5.01 & 131.46 & 215.36 & Aye et al. (2011) \\
China & 1235.6 & - & - & - & 1095.6 & 2331.20 & $\begin{array}{l}\text { Zhang et al. (2013) } \\
\text { Baral et al. }(2009)\end{array}$ \\
Nepal & 634.56 & - & - & - & - & 634.56 & Tshering (2019) \\
Bhutan & 211.09 & - & - & - & - & 211.09 & FSI (2019) \\
Sikkim & 53 & 16.07 & 1.51 & 1.99 & 98.69 & 171.04 & FSI (2019) \\
Meghalaya & 30.55 & 8.74 & 0.43 & 2.53 & 63.46 & 105.72 & FSI (2019) \\
Tripura & 32.44 & 7.14 & 0.38 & 2.81 & 55.68 & 98.44 & FSI (2019) \\
Assam & 30.3 & 7.47 & 0.39 & 2.55 & 55.66 & 95.37 & FSI (2019) \\
Manipur & 26.55 & 7.9 & 0.3 & 2.33 & 69 & 106.08 & FSI (2019) \\
Arunachal Pradesh & 49.61 & 15.05 & 1.17 & 2.31 & 89.5 & 157.65 & FSI (2019) \\
Mizoram & 24.98 & 5.51 & 0.25 & 2.51 & 53.7 & 108.54 & \\
\hline
\end{tabular}

Abbreviations: AGB-Above Ground Biomass; BGB-Below Ground Biomass; SOC-Soil Organic Carbon; tha ${ }^{-1}$ - Tonnes per hectare

to $207 \mathrm{Mg} \mathrm{C} \mathrm{ha}^{-1}$ using the best-fit models.

\section{GEOGRAPHICAL DISTRIBUTION OF PUBLICA- TIONS}

The geographical distribution of publications as an indicator of the research productivity has become a field of interest. The trend of publications was analysed for four decades from the year 1980 to 2020 . The majority of publications on biomass/carbon estimation in the Himalaya hotspot are from Eastern Himalaya $(51 \%)$, while $27 \%$ are from Central Himalaya and $22 \%$ from Western Himalaya (Fig. 2). In the Western Himalaya, there is no evidence of papers being published in journals during 1980-1990 and the number of publications accessed for 1991-2000 was only three. However, the decade between 2011 and 2020 was particularly significant, with a total of 38 articles. Out of 41 publications, the majority of the studies were carried out in Himachal Pradesh (32\%), followed by Kashmir Himalaya and Pakistan (20\%) and Uttarakhand $(17 \%)$. Doon Valley comprised only $7 \%$ of the publications, whereas only one publication are from Punjab and Haryana. Similarly, towards the Central Himalaya, the number of publications during 19801990 and 1991-2000 was 11 and 4, respectively, while the number of research studies increased during 20012010 and 2011-2020 as 11 and 24, respectively. Among 50 publications, 29 publications (58\%) are from Kumaun,

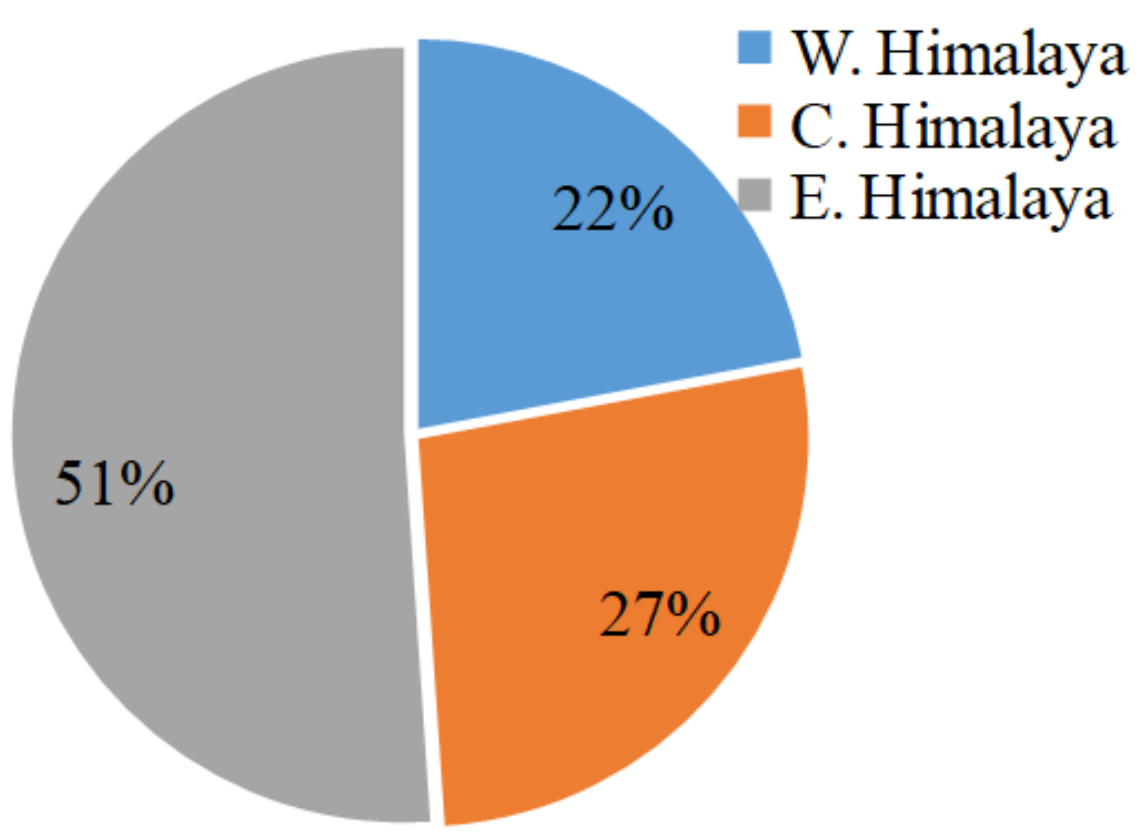

Fig. 2. Percentage record of carbon related publications in the Himalayan region. 


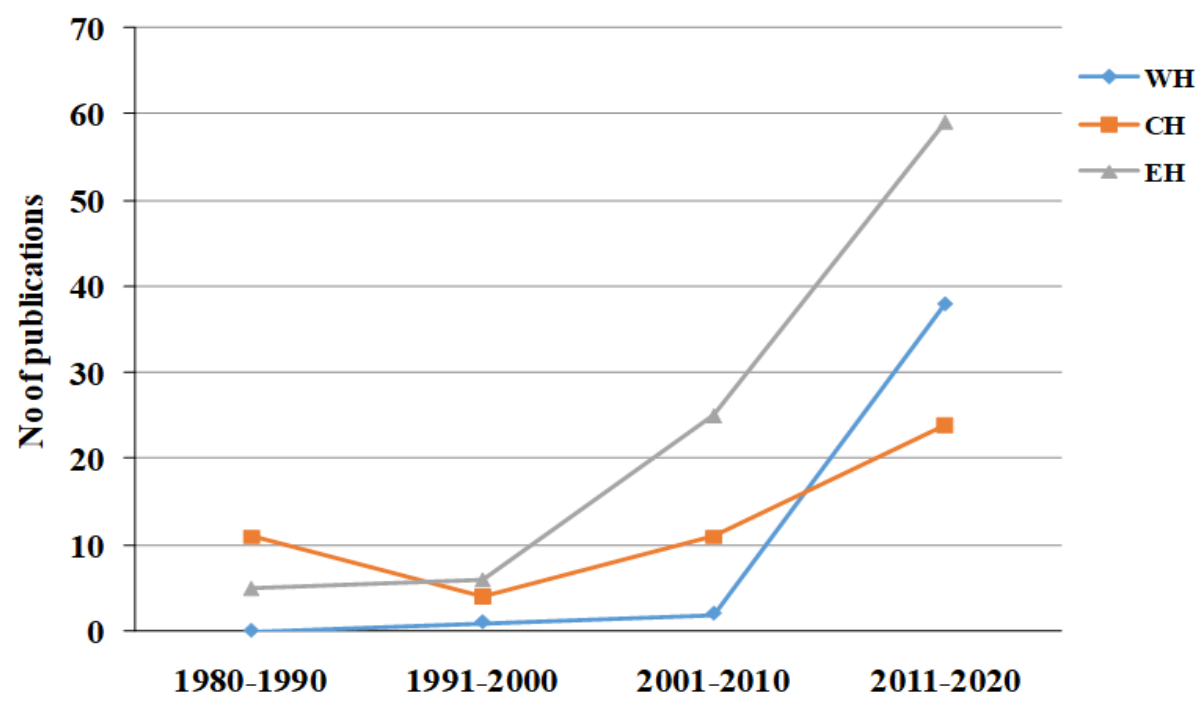

Fig. 3. Pattern of carbon related publications from the Himalaya hotspot.

$32 \%$ from Garhwal and $10 \%$ from Tarai region. Our review shows that a huge number of papers were published from the Eastern Himalaya (Fig.3). Between 1980 and present, 95 publications were documented. Nepal and north-east region of India are the most studied area, comprising $62 \%$ of the total. China (25\%) is the second most studied area, followed by Myanmar (9\%), whereas Bhutan (3\%) and Sikkim (1\%) are comparatively less studied in the Eastern Himalaya. It is to be noted that the concept 'biomass/carbon estimation' exhibits a sudden and marked increase in publications after 2001. The pattern of the research interest indicates that there is a requirement for prioritizing future research in the Himalaya.

\section{Conclusion}

The Himalayan forests have the potential to mitigate climate change and global warming. The present communication has highlighted different aspects of estimation of forest's biomass to assess the carbon loss and gain in the Himalaya hotspot. Although, there have been several scientific studies conducted from the western to eastern extensions of the Himalaya hotspot forests related to biomass and carbon stocks, there is a need to develop methods for precise estimation rather than the conventional laborious approach. From policy standpoint, there is a need to recognize the essence of the pristine Himalayan region for their carbon sequestration and ecosystem services.

\section{ACKNOWLEDGEMENTS}

The first author is grateful to Council of Scientific \& Industrial Research (CSIR), New Delhi, for financial assistance. The authors are also thankful to the Department of Botany, University of Calcutta for all the necessary help required in writing this manuscript.

\section{Conflict of interests}

The authors declare that they have no conflict of interests.

\section{REFERENCES}

1. Aboal, J.R., Arévalo, J.R. and Fernández, Á. (2005). Allometric relationships of different tree species and stand above ground biomass in the Gomera laurel forest (Canary Islands). Flora-Morphology Distribution Functional Ecology of Plants, 200(3): 264-274.

2. Adhikari, B., Lodhiyal, N. and Lodhiyal, L.S. (2020). Assessment of crop yield productivity and carbon sequestration in agroforestry systems in Central Himalaya, India. Agroforestry Systems, 94(1): 281-296. https:// doi.org/10.1007/s10457-019-00388-2

3. Alamgir, M. and Al-Amin, M. (2007). Organic carbon storage in trees within different Geopositions of Chittagong (South) Forest Division Bangladesh. Journal of Forestry Research, 18(3): 174. http://dxdoi.org/10.1007/s11676007-0036-6

4. Amir, M., Liu, X., Ahmad, A., Saeed, S., Mannan, A. and Muneer, M.A. (2018). Patterns of biomass and carbon allocation across chronosequence of chir pine (Pinus roxburghii) forest in Pakistan: inventory-based estimate. Advances in Meteorology, 2018: 3095691.

5. Anaya, J.A., Chuvieco, E. and Palacios-Orueta, A. (2009). Aboveground biomass assessment in Colombia: A remote sensing approach. Forest Ecology and Management, 257 (4): $1237-1246$.

6. Apollo, M. (2017). The population of Himalayan regionsby the numbers: Past present and future W: R. Efe, M. Öztürk (red.). Contemporary Studies in Environment and Tourism Cambridge: Scholars Publishing, pp. 145-160.

7. Arora, G., Chaturvedi, S., Kaushal, R., Nain, A., Tewari, S., Alam, N.M. and Chaturvedi, O.P. (2014). Growth biomass carbon stocks and sequestration in an age series of Populus deltoides plantations in Tarai region of central Himalaya. Turkish Journal of Agriculture and Forestry, 38 (4): 550-560.

8. Arora, P. and Chaudhry, S. (2014). Carbon sequestration in tree plantations at Kurukshetra in Northern India. American International Journal of Research in Formal Applied 
and Natural Sciences, 5(1): 65-70.

9. Aye, Y.Y., Lee, D.K., Park, Y.D. and Park, G.E. (2011). Carbon storage of 15-year-old Xylia xylocarpa and Pterocarpus macrocarpus plantations in the Katha District of Myanmar Forest. Science and Technology, 7(3): 134-140. https://doi.org/10.1080/21580103.2011.594613

10.Aziz, S., Chughtai, F.M., Shaheen, H., Khan, R.W.A. and Dar, M.E.U.I. (2019). Biomass and soil carbon stocks assessment in western himalayan alpine and subalpine vegetation zones of Kashmir. Pakistan Journal of Botany, 51(3): 973-978.

11.Baishya, R. and Barik, S.K. (2011). Estimation of tree biomass carbon pool and net primary production of an oldgrowth Pinus kesiya Royle ex. Gordon forest in northeastern India. Annals of Forest Science, 68(4): 727-736.

12.Banik, B., Deb, D., Deb, S. and Datta, B.K. (2018). Assessment of biomass and carbon stock in sal (Shorea robusta Gaertn.) forests under two management regimes in Tripura, northeast India. Journal of Forest and Environmental Science, 34(3):209-223.

13.Baral, S.K., Malla, R. and Ranabhat, S. (2009). Aboveground carbon stock assessment in different forest types of Nepal. Banko Janakari 19(2): 10-14.

14.Beffasti, L. and Galanti V (eds.) (2011). Myanmar Protected Areas: Context Current Status and Challenges. Instituto Oikos Ancora Libri Milan, pp. 86

15.Bhandari, S.K. and Neupane, H. (2014). Allometric equations for estimating the above-ground biomass of Castanopsis indica at juvenile stage. Banko Janakari, 24(1): 14-22.

16.Bhardwaj, D.R., Banday, M., Pala, N.A. and Rajput, B.S. (2016). Variation of biomass and carbon pool with NDVI and altitude in sub-tropical forests of northwestern Himalaya. Environmental Monitoring and Assessment, 188(11): 635.

17.Bhatt, D., Chandra Sekar, K., Rawal, R.S., Nandi, S.K. and Dhyani, P.P. (2016). Tree diversity of Western Himalaya. GB Pant Institute of Himalayan Environment and Development, Almora, Uttarakhand, India.

18.Bhatta, S.P., Sharma, K.P. and Balami, S. (2018). Variation in carbon storage among tree species in the planted forest of Kathmandu, Central Nepal. Current Science, 115 (2): 274-282.

19.Bolin, B. (1977). Changes of land biota and their importance for the carbon cycle. Science, 196(4290): 613615.

20.Brown, S. (1993). Tropical forests and the global carbon cycle: the need for sustainable land-use patterns. Agriculture Ecosystems and Environment, 46(1-4): 31-44.

21.Brown, S., Gillespie, A.J. and Lugo, A.E. (1989). Biomass estimation methods for tropical forests with applications to forest inventory data. Forest Science, 35(4): 881-902.

22.Brown, S.L., Schroeder, P. and Kern, J.S. (1999). Spatial distribution of biomass in forests of the eastern USA. Forest Ecology and Management, 123(1): 81-90.

23.CEPF (Critical Ecosystem Partnership Fund) (2019). Biodiversity Hotspots. Retrieved April, 2020 from https:// wwwcepfnet/stories/biodiversity-hotspots

24.Chisanga, K., Bhardwaj, D.R., Pala, N.A. and Thakur, C.L. (2018). Biomass production and carbon stock inventory of high-altitude dry temperate land use systems in North Western Himalaya. Ecological Processes, 7(1): 22. https://doi.org/10.1186/s13717-018-0134-8

25.Dad, J.M. (2019). Organic carbon stocks in mountain grassland soils of north western Kashmir Himalaya: spa- tial distribution and effects of altitude plant diversity and land use. Carbon Management, 10(2): 149-162. https:// doi.org/10.1080/17583004.2019.1568137

26.Dar, D.A. and Sahu, P. (2018). Assessment of biomass and carbon stock in temperate forests of Northern Kashmir Himalaya, India. Proceedings of the International Academy of Ecology and Environmental Sciences, 8(2): 139-150.

27.Dar, J.A., Rather, M.Y., Subashree, K., Sundarapandian, S. and Khan, M.L. (2017). Distribution patterns of tree understorey and detritus biomass in coniferous and broadleaved forests of Western Himalaya, India. Journal of Sustainable Forestry, 36(8): 787-805.

28.Devi, A.S. and Singh, K.S. (2019). Estimation of soil carbon sequestration and flux through soil respiration under Muli Bamboo forests in North-East India. Ecology Environment and Conservation, 25: 129-133.

29.Devi, B., Bhardwaj, D.R., Panwar, P., Pal, S., Gupta, N.K. and Thakur, C.L. (2012). Carbon allocation sequestration and carbon dioxide mitigation under plantation forests of north western Himalaya India. Annals of Forest Research, 56(1): 123-135.

30.Devi, L.S. and Yadava, P.S. (2015). Carbon stock and rate of carbon sequestration in Dipterocarpus forests of Manipur, Northeast India. Journal of Forestry Research, 26(2): 315-322.

31.Devi, L.S.andYadava, P.S. (2009). Aboveground biomass and net primary production of semi-evergreen tropical forest of Manipur, north-eastern India. Journal of Forestry Research, 20(2): 151-155.

32.Dhanwantri, K., Sharma, P., Mehta, S. and Prakash, P. (2014). Carbon sequestration its methods and significance. Environmental Sustainability: Concepts Principles Evidences and Innovations, 151-162.

33.Dimri, S., Baluni, P. and Sharma, C.M. (2014). Growing stock of various pure conifer forest types of central (Garhwal) Himalaya, India. International Journal of Current Research and Review, 6(22): 45-49.

34.Drake, J.B., Knox, R.G., Dubayah, R.O., Clark, D.B., Condit, R., Blair, J.B. and Hofton, M. (2003). Aboveground biomass estimation in closed canopy neotropical forests using lidar remote sensing: Factors affecting the generality of relationships. Global Ecology and Biogeography, 12 (2): 147-159.

35.ENVIS Centre on Wildlife and Protected Areas (2019). Protected Area of India. Retrieved April, 2020 from http:// wiienvisnicin/Database/Protected Area 854aspx

36.Friedlingstein, P., Jones, M., O'Sullivan, M., Andrew, R., Hauck, J., Peters, G., Peters, W., Pongratz, J., Stitch, S., Le Quéré, C. and DBakker, O. (2019). Global carbon budget 2019. Earth System Science Data, 11(4): 17831838. https://doi.org/10.3929/ethz-b-000385668

37.FSI (2019). Carbon Stock in India's Forests India. State of Forest Report 2019 Vol 1. Retrieved April, 2020 from http://fsinicin/isfr19/vol1/chapter9pdf

38.Gaillardet, J. and Galy, A. (2008). Himalaya-Carbon Sink or Source?.Science, 320(5884): 1727-1728.

39.Gairola, S., Sharma, C.M., Ghildiyal, S.K. and Suyal, S. (2011). Live tree biomass and carbon variation along an altitudinal gradient in moist temperate valley slopes of the Garhwal Himalaya (India). Current Science, 100: 18621870.

40.Gibbs, H.K., Brown, S., Niles, J.O. and Foley, J.A. (2007). Monitoring and estimating tropical forest carbon stocks: making REDD a reality. Environmental Research Letters, 
2(4): 045023.

41.Giri, N., Kumar, R., Rawat, L. and Kumar, P. (2014). Development of biomass expansion factor (BEF) and estimation of carbon pool in Ailanthus excela Roxb plantation. Journal of Chemical Engineering and Process Technology, 5(6): 1000210. https://doi.org/10.4172/2157-7048.1 000210

42.Gogoi, A., Sahoo, U.K. and Singh, S.L. (2017). Assessment of biomass and total carbon stock in a tropical wet evergreen rainforest of Eastern Himalaya along a disturbance gradient. Journal of Plant Biology and Soil Health, 4 (1): 8.

43.Gosain, B.G., Negi, G.C.S., Dhyani, P.P., Bargali, S.S. and Saxena, R. (2015). Ecosystem services of forests: Carbon Stock in vegetation and soil components in a watershed of Kumaun Himalaya, India. International Journal of Ecology and Environmental Science, 41(3-4): 177-188.

44.Goswami, S., Verma, K.S. and Kaushal, R. (2014). Biomass and carbon sequestration in different agroforestry systems of a Western Himalayan watershed. Biological Agriculture and Horticulture, 30(2):88-96. https:// doi.org/10.1080/01448765.2013.855990

45.Gurung, M.B., Bigsby, H., Cullen, R., Manandhar, U. (2015). Estimation of carbon stock under different management regimes of tropical forest in the Terai Arc Landscape, Nepal. Forest Ecology and Management, 356:144152.

46.Hame, T., Salli, A., Andersson, K. and Lohi, A. (1997). A new methodology for the estimation of biomass of conifer dominated boreal forest using NOAA AVHRR data. International Journal of Remote Sensing, 18(15): 3211-3243.

47.Hudak, A.T., Strand, E.K., Vierling, L.A., Byrne, J.C., Eitel, J.U., Martinuzzi, S. and Falkowski, M.J. (2012). Quantifying aboveground forest carbon pools and fluxes from repeat LiDAR surveys. Remote Sensing of Environment, 123:25-40.

48.IEA (International Energy Agency) (2019). Global Energy and CO2 Status Report. Retrieved April, 2020 from https:// wwwieaorg/reports/global-energy-co2-status-report-2019/ emissions\#abstract

49.IPCC (Intergovernmental Panel on Climate Change) (2012b). Meeting report of the Intergovernmental Panel on Climate Change expert meeting on geoengineering. In: Edenhofer, O., Pichs-Madruga, R., Sokona, Y., Field, C., Barros, V., Stocker, T.F., Dahe, Q., Minx, J., Mach, K., Plattner, G.K. and Schlömer, S. (eds) Intergovernmental Panel on Climate Change Expert Meeting on Geoengineering Lima.

50.Jina, B.S., Sah, P., Bhatt, M.D. and Rawat, Y.S. (2008). Estimating carbon sequestration rates and total carbon stockpile in degraded and non-degraded sites of Oak and Pine forest of Kumaun Central Himalaya. Ecoprint: An International Journal of Ecology, 15: 75-81.

51.Joshi, N.R., Tewari, A. and Chand, D.B. (2013). Impact of Forest fire and aspect on phytosociology tree biomass and carbon stock in Oak and Pine mixed Forests of Kumaun central Himalaya India. Researcher, 5(3): 1-8.

52.Joshi, R.K. and Dhyani, S. (2019). Biomass, carbon density and diversity of tree species in tropical dry deciduous forests in Central India. Acta Ecologica Sinica, 39(4): 289299. https://doi.org/10.1016/j.chnaes.2018.09.009

53.Kalita, R.M., Das, A.K. and Nath, A.J. (2017). Carbon stock and sequestration potential in biomass of tea agroforestry system in Barak Valley, Assam, North East India.
International Journal of Ecology and Environmental Sciences, 42(5): 107-114.

54.Kanime, N., Kaushal, R., Tewari, S.K., Raverkar, K.P., Chaturvedi, S. and Chaturvedi, O.P. (2013). Biomass production and carbon sequestration in different treebased systems of Central Himalayan Tarai region. Forests Trees and Livelihoods, 22(1): 38-50.

55.Karan, P.P. (1987). Population characteristics of the Himalayan region. Mountain Research and Development, 7: 271-274.

56.Kaushal, R., Subbulakshmi, V., Tomar, J.M.S., Alam, N.M., Jayaparkash, J., Mehta, H. and Chaturvedi, O.P. (2016). Predictive models for biomass and carbon stock estimation in male bamboo (Dendrocalamus strictus L.) in Doon valley, India, Acta Ecologica Sinica, 36(6): 469-476. http://dx.doi.org/10.1016/j.chnaes.2016.07.003

57.Kebede, B. and Soromessa, T. (2018). Allometric equations for aboveground biomass estimation of Olea europaea L subspcuspidata in Mana Angetu Forest. Ecosystem Health and Sustainability, 4(1): 1-12. https:// doi.org/10.1080/20964129.2018.1433951

58.Ketterings, Q.M., Coe, R., van Noordwijk, M. and Palm, C.A. (2001). Reducing uncertainty in the use of allometric biomass equations for predicting above-ground tree biomass in mixed secondary forests. Forest Ecology and management, 146(1-3): 199-209.

59.Khurana, P. (2012). A study on carbon sequestration in natural forests of India. Journal of Applied and Natural Science, 4 (1): 132-136.

60.Koppad, A.G., Banavasi, P.P. and Sarfin, S. (2020). Assessment of land use land cover and carbon sequestration in forests of Joida Taluk of Uttar Kannada district using Remote sensing technique. Journal of Applied and Natural Science, 12(3): 344-348. https://doi.org/10.31018/ jans.v12i3.2317

61.Kumar, A., Sharma, M.P. (2015). Estimation of carbon stocks of Balganga Reserved Forest Uttarakhand India. Forest science and technology, 11(4): 177-181.

62.Kumar, K., Joshi, R., Verma, R. and Dhayani, P. (2018). Governance for sustaining Himalayan Ecosystem (G$\mathrm{SHE})$, Guidelines and Best Practices, Ministry of Environment and Forest, Government of India (Updated version).

63.Kusmana, C., Hidayat, T., Tiryana, T. and Rusdiana, O. (2018). Allometric models for above-and below-ground biomass of Sonneratia spp. Global ecology and conservation, 15: e00417.

64.Lal, R. (2008). Carbon sequestration. Philosophical Transactions of the Royal Society B: Biological Sciences, 363(1492): 815-830.

65.Lodhiyal, N. and Lodhiyal, L.S. (2003). Biomass and net primary productivity of Bhabar Shisham forests in central Himalaya, India. Forest Ecology and Management, 176(13): $217-235$

66.Lu, D. (2006). The potential and challenge of remote sensing based biomass estimation. International Journal of Remote Sensing, 27(7): 1297-1328.

67.Mahato, S., Dasgupta, S. and Todaria, N.P. (2016). Tree and soil carbon stock by community managed forests in Garhwal Himalaya. Plant Archives, 16(2): 805-811.

68.Majumdar, K., Choudhary, B.K. and Datta, B.K. (2016). Aboveground woody biomass, carbon stocks potential in selected tropical forest patches of Tripura, Northeast India. Open Journal of Ecology, 6(10): 598. http:// dx.doi.org/10.4236/oje.2016.610057 
69.Mandal, G. and Joshi, S.P. (2015). Estimation of aboveground biomass and carbon stock of an invasive woody shrub in the subtropical deciduous forests of Doon Valley, western Himalaya, India. Journal of Forestry Research, 26 (2): 291-305.

70.Mandal, R.A., Yadav, B.K.V., Yadav, K.K., Dutta, I.C. and Haque, S.M. (2013). Development of allometric equation for biomass estimation of Eucalyptus camaldulensis: a study from Sagarnath Forest, Nepal. International Journal of Biodiversity and Ecosystems, 1(1): 1-7.

71.Manickam, V., Krishna, I.V.M., Shanti, S.K. and Radhika, R. (2014) Biomass Calculations for Carbon Sequestration in Forest Ecosystem. Journal of Energy, 2(1): 30-38.

72.Masera, O.R., Garza-Caligaris, J.F., Kanninen, M., Karjalainen, T., Liski, J., Nabuurs, G.J. and Mohren, G.M.J. (2003). Modeling carbon sequestration in afforestation agroforestry and forest management projects: the CO2FIX V 2 approach. Ecological modelling, 164(2-3): 177-199

73.Mishra, A.K., Kshama, S., Kailash, S., Shalini, S., Md, S. and Ali, S. (2014). Carbon sequestered through biomass and soil organic carbon dynamics in Jatropha curcas L. Ecology Environment and Conservation, 20(2): 561-565.

74.Mishra, G. and Sarkar, A. (2019). Studying the relationship between total organic carbon and soil carbon pools under different land management systems of Garo hills, Meghalaya. Journal of Environmental Management, 257: 110002. https://doi.org/10.1016/j.jenvman.2019.110002

75.Mittermeier, R.A., Myers, N., Thomsen, J.B., Da Fonseca, G.A. and Olivieri, S. (1998). Biodiversity hotspots and major tropical wilderness areas: approaches to setting conservation priorities. Conservation Biology, 12(3): 516520.

76.Montes, N., Gauquelin, T., Badri, W., Bertaudiere, V. and Zaoui, E.H. (2000). A non-destructive method for estimating above-ground forest biomass in threatened woodlands. Forest Ecology and Management, 130(1-3): 37-46.

77.Murali, K.S., Bhat, D.M. and Ravindranath, N.H. (2005). Biomass estimation equations for tropical deciduous and evergreen forests. International Journal of Agricultural Resources Governance and Ecology, 4(1): 81-92.

78.Myers, N. (1988). Threatened biotas:" hot spots" in tropical forests. Environmentalist, 8(3): 187-208.

79.Myers, N. (1990). The biodiversity challenge: expanded hot-spots analysis. Environmentalist, 10(4): 243-256.

80.Nair, P.K.R. (2012). Carbon sequestration studies in agroforestry systems: a reality-check. Agroforestry Systems, 86(2): 243-253.

81.Nautiyal, N. and Singh, V. (2013). Carbon stock potential of oak and pine forests in Garhwal region in Indian Central Himalayas. Journal of Pharmacognosy and Phytochemistry, 2(1): 43-48.

82.Negi, S.P. (2009). Forest cover in Indian Himalayan states-An overview. Indian Journal of Forestry, 32(1): 1-5.

83.Nelson, R., Krabill, W. and Tonelli, J. (1988). Estimating forest biomass and volume using airborne laser data. Remote Sensing of Environment, 24(2): 247-267.

84.Niirou, N. and Gupta, A. (2017). Phytosociological analysis and carbon stocks for trees in different land uses in Senapati district of Manipur, India. Pleione, 11(1): 64-70.

85.Oo, M.Z., Shin, T., Oosumi, Y. and Kiyono, Y. (2006). Biomass of planted forests and biotic climax of shrub and grass communities in the central dry zone of Myanmar. Bulletin-Forestry and Forest Products Research Institute Ibaraki, 5(4): 271-288.
86.Pala, N.A., Negi, A.K., Gokhale, Y., Shah, S. and Kumar, M. (2016). Community structure and plant diversity of community based religious conserved forests of Garhwal Himalaya, India. Journal of Earth Science and Climate Change, 7(2): 334.https://doi.org/10.4172/2157-7617.1 000334

87.Palchowdhuri, Y., Vyas, A., Kushwaha, D., Roy, A. and Roy, P.S. (2016). Quantitative assessment of aboveground carbon dynamics in temperate forest of Shimla district. Tropical Ecology, 57(4): 825-837.

88.Pan, Y., Birdsey, R.A., Fang, J., Houghton, R., Kauppi, P.E., Kurz, W.A., Phillips, O.L., Shvidenko, A., Lewis, S.L., Canadell, J.G., Ciais, P., Jackson, R.B., Pacala, S.W., McGuire, A.D., Piao, S., Rautiainen, A., Sitch, S. and Hayes, D. (2011). A large and persistent carbon sink in the world's forests. Science, 333(6045): 988-993.

89.Pandey, A., Arunachalam, K., Thadani, R. and Singh, V. (2020). Forest degradation impacts on carbon stocks tree density and regeneration status in banj oak forests of Central Himalaya. Ecological Research, 35(1): 208-218.

90.Pandit, S., Tsuyuki, S. and Dube, T. (2018). Estimating above-ground biomass in sub-tropical buffer zone community forests Nepal using Sentinel 2 data. Remote Sensing, 10(4): 601.

91.Pant, H. and Tewari, A. (2014). Carbon sequestration in Chir-Pine (Pinus roxburghii Sarg.) forests under various disturbance levels in Kumaun Central Himalaya. Journal of Forestry Research, 25(2): 401-405.

92.Penman, J., Gytarsky, M., Hiraishi, T., Krug, T., Kruger, D., Pipatti, R., Buendia, L., Miwa, K., Ngara, T., Tnabe, K. and Wagner, F. (2003). Good practice guidance for land use land-use change and forestry. IPCC National Greenhouse Gas Inventories Programme and Institute for Global Environmental Strategies Kanagawa Japan.

93.Pires, J.C.M., Martins, F.G., Alvim-Ferraz, M.C.M. and Simões, M. (2011). Recent developments on carbon capture and storage: an overview. Chemical Engineering Research and Design, 89(9): 1446-1460.

94.Post, W.M., Peng, T.H., Emanuel, W.R., King, A.W., Dale V.H. and De Angelis, D.L. (1990). The global carbon cycle. American Scientist, 78(4): 310-326.

95.Poudel, B.S., Gautam, S.K. and Bhandari, D.N. (2011). Above-ground tree biomass and allometric relationships of Cinnamomum tamala grown in the western hill regions of Nepal. Banko Janakari, 21(1): 3-12.

96.Rabha, D. (2014). Aboveground biomass and carbon stocks of an undisturbed regenerating sal (Shorea robusta Gaertn.) forest of Goalpara district, Assam, northeast India. International Journal of Environment, 3(4): 147-155.

97.Rai, I.D., Padalia, H., Singh, G., Adhikari, B.S. and Rawat, G.S. (2020). Vegetation dry matter dynamics along treeline ecotone in Western Himalaya India. Tropical Ecology, 1-12. https://doi.org/10.1007/s42965-020-00067-9

98.Rai, S., Pandey, A. and Badola, H.K. (2018). Biomass and carbon stock estimation across the timberline of Khangchendzonga National Park, Eastern Himalaya, India. Taiwania, 63(4): 311-320.

99.Rajput, B.S., Bhardwaj, D.R. and Pala, N.A. (2015). Carbon dioxide mitigation potential and carbon density of different land use systems along an altitudinal gradient in north-western Himalayas. Agroforestry Systems, 89(3): 525-536.

100.Rana, S., Bargali, K., Bargali, S.S. (2015). Assessment of plant diversity regeneration status biomass and carbon 
stock in a Central Himalayan cypress forest. International Journal of Biodiversity and Conservation, 7(6): 321-329.

101.Rashid, I., Bhat, M.A. and Romshoo, S.A. (2017). Assessing changes in the above ground biomass and carbon stocks of Lidder valley, Kashmir Himalaya, India. Geocarto International, 32(7): 717-734. https:// doi.org/10.1080/10106049.2016.1188164

102.Ravindranath, N.H. and Ostwald, M. (2008). Methods for estimating above-ground biomass. Carbon inventory methods handbook for greenhouse gas inventory carbon mitigation and roundwood production projects, pp. 113147.

103.Salunkhe, O., Khare, P.K., Kumari, R. and Khan, M.L. (2018). A systematic review on the aboveground biomass and carbon stocks of Indian forest ecosystems. Ecological Processes, 7(1): 17. https://doi.org/10.1186/s13717-0180130-z

104.Sandeep, S., Sivaram, M., Henry, M. and Birigazzi, L. (2014). Inventory of volume and biomass tree allometric equations for South Asia. KFRI, Peechi, India Food \& Agriculture Organization of the United Nations Rome Italy. UN-REDD Programme MRV report 15.

105.Seeland, K. (2000). National Park policy and wildlife problems in Nepal and Bhutan. Population and Environment, 22(1): 43-62.

106.Shaheen, H., Khan, R.W.A., Hussain, K., Ullah, T.S., Nasir, M. and Mehmood, A. (2016). Carbon stocks assessment in subtropical forest types of Kashmir Himalayas. Pakistan Journal of Botany, 48(6): 2351-2357.

107.Shahid, M. and Joshi, S.P. (2015). Biomass and carbon stock assessment in moist deciduous forests of Doon valley, western Himalaya, India. Taiwania, 60: 71-76.

108.Sharma, C.M., Gairola, S., Baduni, N.P., Ghildiyal, S.K. and Suyal, S. (2011). Variation in carbon stocks on different slope aspects in seven major forest types of temperate region of Garhwal Himalaya, India. Journal of Biosciences, 36(4): 701-708.

109.Sharma, E., Tse-ring, K., Chettri, N., Shrestha, A. and Kathmandu, N. (2008). Biodiversity in the Himalayastrends, perception and impacts of climate change. In: Proceedings of the International Mountain Biodiversity Conference Kathmandu.

110.Sharma, K. (ed) (1999). Encyclopaedia of Himalayas. Vol 3 Central Himalayas. Anmol Publications Pvt Ltd.

111.Sharma, S.B., Singh, N.S. and Lalruatfela, R. (2018). Tree diversity and carbon stocks of Hmuifang forest, Mizoram. International Journal of Research in BioSciences, 7 (1): 87-99.

112.Sheikh, M.A., Kumar, M., Todaria, N.P. and Pandey, R. (2020). Biomass and soil carbon along altitudinal gradients in temperate Cedrus deodara forests in Central Himalaya, India: Implications for climate change mitigation. Ecological Indicators, 111: 106025. https:// doi.org/10.1016/j.ecolind.2019.106025

113.Shrestha, U.B., Shrestha, S., Chaudhary, P. and Chaudhary, R.P. (2010). How representative is the protected areas system of Nepal?.Mountain Research and Development, 30(3): 282-294.

114.Singh, J.S., Tiwari, A.K. and Saxena, A.K. (1985). Himalayan forests: A net source of carbon for the atmosphere. Environmental Conservation, 12(1): 67-69.

115.Singh, S.K. and Rawat, G.S. (1999). Floral diversity and vegetation structure in great Himalayan national park, Western Himalaya. Wildlife Institute of India 1-130.
116.Singh, S.P., Singh, V. and Skutsch, M. (2010). Rapid warming in the Himalayas: Ecosystem responses and development options. Climate and Development, 2(3): 221 -232 .

117.Stephen, A., Suresh, R. and Livingstone, C. (2015). Indian Biodiversity: Past Present and Future. International Journal of Environment and Natural Sciences, 7: 13-28.

118.Tashi, S., Keitel, C., Singh, B. and Adams, M. (2017). Allometric equations for biomass and carbon stocks of forests along an altitudinal gradient in the eastern Himalayas. Forestry: An International Journal of Forest Research, 90(3): 445-454. https://doi.org/10.1093/forestry/ cpx003

119.Thant, Y.M., Kanzaki, M., Ohta, S. and Than, M.M. (2012). Carbon sequestration by mangrove plantations and a natural regeneration stand in the Ayeyarwady Delta, Myanmar. Tropics, 21(1): 1-10.

120.Thokchom, A. and Yadava, P.S. (2017). Biomass and carbon stock along an altitudinal gradient in the forest of Manipur, Northeast India. Tropical Ecology, 58(2): 389396.

121.Toky, O.P. and Bisht, R.P. (1993). Above-ground and below-ground biomass allocation in important fuelwood trees from arid north-western India. Journal of Arid Environments, 25(3): 315-320.

122.Tse-ring, K., Sharma, E., Chettri, N. and Shrestha, A.B. (eds.) (2010). Climate Change Impact and Vulnerabilityin the Eastern Himalayas - Synthesis Report Climate change vulnerability of mountain ecosystems in the Eastern Himalayas. International Centre for Integrated Mountain Development (ICIMOD).

123.Tshering, S. (2019). Importance Value Index and Assessment of Carbon Stocks in Western Bhutan Himalaya (Thimphu). Current Journal of Applied Science and Technology, 32: 1-8.

124.Uddin, R., Ansari, L., Ahmad, A., Ullah, S., Munir, M. amd Sher, K. (2019). Soil Analysis Species Composition and Carbon Dynamics of Abies Pindrow Forest of Dir Kohistan, Pakistan. Applied Ecology and Environmental Research, 17(4): 8049-8058. http://dx.doi.org/10.15666/ aeer/1704_80498058

125.Vaidya, P., Verma, K.S., Bhardwaj, S.K., Brahmi, M.K., Sharma, D.P. and Gupta, R.K. (2017). Allometric Models for Estimating Tree Biomass and Soil Carbon Stocks of Small Scale Plantations in Subtropical-Subtemperate Regions of Western Himalayas. Indian Forester, 143(5): 411416.

126.Vashum, K.T. and Jayakumar, S. (2012). Methods to estimate above-ground biomass and carbon stock in natural forests-a review. Journal of Ecosystem and Ecography, 2(4): 1-7.

127.Venkataraman, K. and Sivaperuman, C. (2018). Biodiversity hotspots in India. Indian Hotspots, Springer, Singapore, pp 1-27. https://doi.org/10.1007/978-981-10-660541

128.Verma, A., Tewari, A. and Shah, S. (2012). Carbon storage capacity of high altitude Quercus semecarpifolia forests of Central Himalayan region. Scandinavian Journal of Forest Research, 27(7): 609-618.

129.Vieilledent, G., Vaudry, R., Andriamanohisoa, S.F., Rakotonarivo, O.S., Randrianasolo, H.Z., Razafindrabe, H.N., Rakotoarivony, C.B., Ebeling, J. and Rasamoelina, M. (2012). A universal approach to estimate biomass and carbon stock in tropical forests using generic allometric 
models. Ecological Applications, 22(2): 572-583.

130.Whitehead, D. (2011). Forests as carbon sinks-benefits and consequences. Tree Physiology, 31(9): 893-902. https://doi.org/10.1093/treephys/tpr063

131.Xiao, C.W. and Ceulemans, R. (2004). Allometric relationships for below-and aboveground biomass of young Scots pines. Forest Ecology and Management, 203(1-3): 177-186.

132.Yadav, R.P., Bisht, J.K. and Bhatt, J.C. (2017). Biomass carbon stock under different production systems in the mid hills of Indian Himalaya. Tropical Ecology, 58(1): 1521.

133. Yadava, A.K. (2011). Potential of agroforestry systems in carbon sequestration for mitigating climate changes in Tarai region of central Himalaya. Nature and Science, 9 (6): 72-80.
134.Yaklaşımlar, T.Ü.B.B.G. (2012). Recent approaches in above ground biomass estimation methods. Aegean Geographical Journal, 21(1): 39-51.

135.Zhang, X., Zhang, X., Han, H., Shi, Z and, Yang, X. (2019). Biomass Accumulation and Carbon Sequestration in an Age-Sequence of Mongolian Pine Plantations in Horqin Sandy Land, China. Forests, 10(2): 197. https:// doi.org/10.3390/f10020197

136.Zhang, Y., Gu, F., Liu, S., Liu, Y. and Li, C. (2013). Variations of carbon stock with forest types in subalpine region of southwestern China. Forest Ecology and Management, 300(2013): 88-95. http://dx.doi.org/10.1016/ j.foreco.2012.06.010

137.Zobel, D.B. and Singh, S.P. (1997). Himalayan forests and ecological generalizations. BioScience, 47(11): 735745 . 